\title{
Penetapan Sima Dalam Konteks Perluasan Wilayah Pada Masa Mataram Kuna: Kajian Berdasarkan Prasasti-Prasasti Balitung (899- $910 \mathrm{M})$
}

\section{Baskoro Daru Tjahjono, Nurhadi Rangkuti}

Keywords: inscription, Ancient Mataram, description, kingdom, politics, governing, context

\section{How to Cite:}

Tjahjono, B. D., \& Rangkuti, N. (1998). Penetapan Sima Dalam Konteks Perluasan Wilayah Pada Masa Mataram Kuna: Kajian Berdasarkan Prasasti-Prasasti Balitung
Arkeologi,
18(1), 40-52.

\section{https://doi.org/10.30883/jba.v18i1.775}
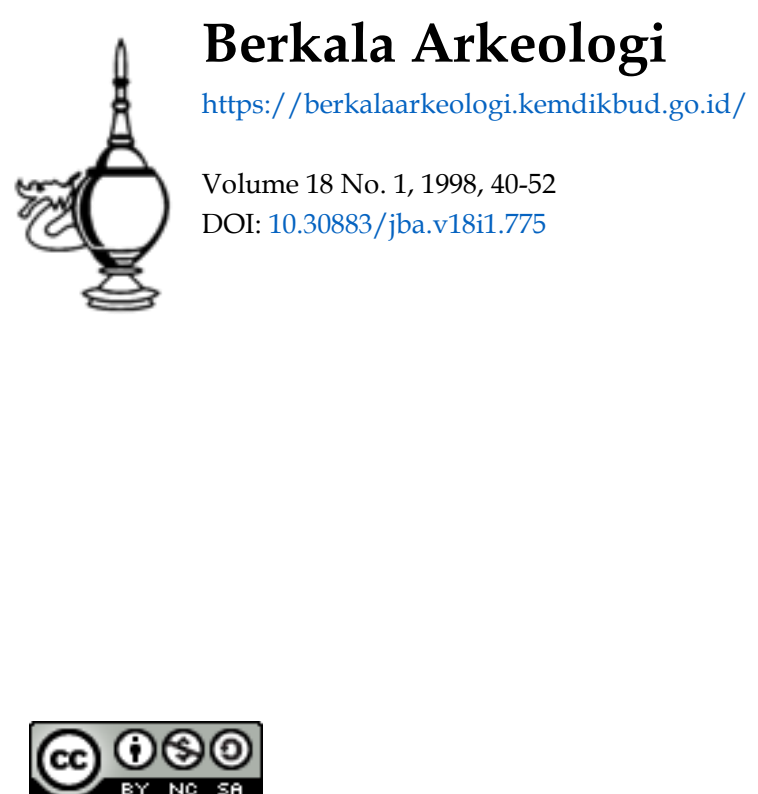

This work is licensed under a Creative Commons Attribution-NonCommercial-ShareAlike 4.0 International License. 


\section{PENETAPAN SIMA DALAM KONTEKS PERLUASAN WILAYAH PADA MASA MATARAM KUNA: \\ Kajian Berdasarkan Prasasti-Prasasti Balitung (899-910 M) \\ Baskoro Daru Tjahjono \\ Nurhadi Rangkuti \\ (Balai Arkeologi Yogyakarta)}

\section{LATAR BELAKANG MASALAH}

Sejak masa pemerintahan Kerajaan Mataram kuna yang wilayah kekuasaannya sebagian besar meliputi wilayah Jawa Tengah, maka di kawasan itu ditemukan banyak prasasti. Banyaknya prasasti yang tersebar di berbagai daerah di wilayah Jawa Tengah merupakan salah satu indikasi yang dapat menunjukkan luas wilayah kekuasaan Kerajaan Mataram kuna pada masa itu. Di antara prasasti-prasasti tersebut ada yang berisi tentang penetapan suatu daerah menjadi daerah sima atau perdikan. Suatu daerah ditetapkan menjadi daerah sima berarti daerah itu dibebaskan dari pajak oleh pemerintah kerajaan. Namun dalam kenyataannya daerah sima ini tidak dibebaskan seratus persen dari beban pajak. Pada dasarnya daerah sima tidak lagi dibebani pajak (drwya haji) dan melakukan kerja bakti (buat haji) untuk raja, tetapi sebagai gantinya daerah itu diwajibkan untuk memelihara sebuah bangunan suci. Jadi beban pajak dan kerja bakti itu hanya diperingan (Casparis, 1956:44-47; Kartakusuma, 1994-1995: 83).

Berbagai alasan mengenai penetapan suatu daerah menjadi sima telah dikemukakan oleh para epigraf. Salah satu yang menarik untuk dikaji adalah pernyataan yang dikemukakan oleh Jan Wisseman Christie (1989), yaitu: banyaknya tanah yang dijadikan sima merupakan suatu cara untuk mengatasi kepadatan penduduk dan pengembangan wilayah persawahan dan permukiman. Dengan demikian suatu wilayah yang tadinya kurang penting menjadi lebih menarik bagi para petani, sehingga memperluas permukiman yang sudah mantap menjadi wilayah yang strategis (Christie, 1989: 6; Rangkuti, 1994: 167). Jika demikian, permasalahannya bagaimanakah konteks penetapan suatu daerah menjadi sima dengan proses perluasan wilayah tersebut?

Di antara raja-raja yang memerintah Kerajaan Mataram kuna yang cukup banyak menerbitkan prasasti salah satunya adalah Dyah Balitung. Raja Balitung memerintah antara tahun 821 sampai $832 \mathrm{C}$ atau 899 sampai $910 \mathrm{M}$ dan mempunyai wilayah kekuasaan yang cukup luas. Prasasti-prasasti yang diterbitkan oleh raja tersebut sebagian di antaranya berisi tentang penetapan sima, melalui prasasti-prasasti ini akan dikaji bagaimana konteks penetapan suatu daerah menjadi sima dengan proses perluasan wilayah pada masa Mataram Kuna. 


\section{MATARAM KUNA PADA MASA PEMERINTAHAN BALITUNG}

Dyah Balitung adalah salah satu raja besar yang bertahta pada masa Kerajaan Mataram Kuna. Raja ini sebenarnya bukan pewaris tahta yang syah, sebab menurut Schrieke, raja-raja yang menunjukkan silsilah seperti halnya Airlangga dalam prasasti Pucangan (963 Saka) dan Raden Wijaya dalam prasasti Kudadu (1216 Saka) tidak berhak penuh atas tahta kerajaan (Schrieke, 1975; Nastiti, 1982: 3). Dyah Balitung naik tahta karena perkawinannya dengan anak Rakai Watuhumalang, penguasa sebelumnya. Prasasti Mantyasih menyebutkan bahwa pada saat menikah ia masih bergelar haji atau raja bawahan. Dyah Balitung adalah seorang pangeran dari daerah Kedu Selatan, yaitu dari daerah Watukura (Nastiti, 1982: 3). Menurut Poerbatjaraka Watukura terletak di tepi Sungai Bogowonto di daerah Purwodadi, Kabupaten Purworejo, Jawa Tengah. Poerbatjaraka juga menafsirkan bahwa seorang raja yang memakai kata dharmma (Rake Watukura Dyah Balitung Sri Dharmmodaya Mahasambhu) adalah raja yang naik tahta karena perkawinan (Poerbatjaraka, 1930: 171-183).

Genealogi raja-raja Mataram Kuna termuat dalam dua prasasti yang dikeluarkan oleh Balitung, yaitu prasasti Mantyasih (907 M) dan prasasti Wanua Tengah III (908 M). Walaupun kedua prasasti ini berurutan tahun terbitnya namun terdapat sedikit perbedaan dalam penyebutan nama raja-raja yang telah berkuasa di kerajaan Mataram Kuna. Dalam prasasti Mantyasih daftar raja-raja yang memerintah Mataram Kuna adalah: Rakai Mataram Sang Ratu Sanjaya, Sri Maharaja Rakai Panangkaran, Sri Maharaja Rakai Panunggalan, Sri Maharaja Rakai Warak, Sri Maharaja Rakai Garung, Sri Maharaja Rakai Pikatan, Sri Maharaja Rakai Kayuwangi, Sri Maharaja Rakai Watuhumalang, dan Sri Maharaja Rakai Watukura Dyah Balitung. Sedangkan dalam prasasti Wanua Tengah III, daftar raja-raja tersebut adalah: Rahyangta ri Mdang, Rake Panangkaran, Rake Panaraban, Rake Warak Dyah Manara, Dyah Gula, Rake Garung, Rake Pikatan Dyah Saladu, Rake Kayuwangi Dyah Lokapala, Dyah Tagwas, Rake Panumwangan Dyah Dewendra, Rake Gurunwangi Dyah Bhadra, Rake Wungkalhumalang Dyah Jbang, dan Rake Watukura Dyah Balitung (Kusen, 1994: 93). Perbedaan daftar nama-nama raja dari dua prasasti tersebut antara lain tidak dicantumkannya nama-nama raja Dyah Gula, Dyah Tagwas, Rake Panumwangan Dyah Dewendra, dan Rake Gurunwangi Dyah Bhadra - yang terdapat pada prasasti Wanua Tengah III - pada prasasti Mantyasih. Menurut Kusen perbedaan ini disebabkan perbedaan latar belakang dikeluarkannya prasasti. Prasasti Mantyasih diterbitkan oleh Balitung dalam rangka melegitimasi dirinya sebagai pewaris tahta yang syah, sehingga yang dicantumkan hanya raja-raja yang berdaulat penuh atas seluruh wilayah kerajaan. Dyah Gula, Dyah Tagwas, Dyah Dewendra, dan Dyah Bhadra tidak pernah berdaulat penuh, terlihat dari singkatnya masa pemerintahan mereka. Sedangkan prasasti Wanua Tengah III dikeluarkan dalam kaitannya dengan perubahan status sawah di Wanua Tengah, sehingga semua penguasa yang 
mempunyai sangkut paut dengan perubahan status sawah dimasukkan dalam daftar (Kusen, 1994: 91)

Selama pemerintahannya, Balitung cukup banyak menerbitkan prasasti (tabel 1) yang tersebar di wilayah Jawa Tengah maupun Jawa Timur. Berdasarkan penemuan prasasti-prasasti tersebut, maka dapat diperkirakan masa pemerintahan serta luas wilayah kekuasaan Raja Balitung pada waktu itu. Prasasti tertua yang menyebut nama Rakai Watukura Dyah Balitung adalah prasasti Têlahap (Kedu) tahun 821 C (899 M), sedangkan yang termuda adalah prasasti Tulangan (Jedung I) tahun $832 \mathrm{C}(910 \mathrm{M})$. Dengan demikian Balitung memerintah dari tahun 821 sampai dengan tahun $832 \mathrm{C}$ (899-910 M) (Wibowo, 1964: 147-154; Dwiyanto, 1981: 7). Bukti-bukti prasasti yang ditinggalkan tersebut menunjukkan bahwa wilayah kekuasaannya meliputi daerah Jawa Tengah dan Jawa Timur, suatu hal yang belum pernah terlihat tanda-tandanya pada raja-raja yang memerintah sebelumnya (Wibowo, 1976:64-76; Dwiyanto, 1981:8).

Tabel 1. Prasasti-Prasasti masa Balitung (899- 910 M)

\begin{tabular}{|c|c|c|c|c|}
\hline No & Nama Prasasti & $\begin{array}{c}\text { Tahun } \\
\text { (Masehi) }\end{array}$ & $\begin{array}{l}\text { Penetapan } \\
\text { Sima }\end{array}$ & Lokasi Penemuan \\
\hline 1. & Têlahap & 899 & - & Kedu, Jawa Tengah \\
\hline 2. & Ayam Têas I & 900 & $\mathrm{~V}$ & Di daerah Purworejo, Jawa Tengah \\
\hline 3. & Ayam Têas II & 901 & $\mathrm{~V}$ & Di daerah Banjarnegara, Jawa Tengah \\
\hline 4. & Taji & 901 & $\mathrm{~V}$ & Daerah Ponorogo, Jawa Timur \\
\hline 5. & Luitan & 901 & $\cdot$ & $\begin{array}{l}\text { Desa Pesanggrahan, Kec. Kesugihan, } \\
\text { Cilacap, Jawa Tengah }\end{array}$ \\
\hline 6. & Kayu Ara Hiwang & 901 & V & Bara Tengah Purworejo, Jawa Tengah \\
\hline 7. & Rongkab & 901 & - & Daerah Pati Jawa Tengah \\
\hline 8. & Watukura & 902 & $\mathrm{~V}$ & Tidak jelas (Jawa Tengah) \\
\hline 9. & Panggumulan $\mathrm{A}$ & 902 & V & $\begin{array}{l}\text { Desa Kembang Arum, Kec. Klegung. } \\
\text { Sleman, DIY }\end{array}$ \\
\hline 10. & Panggumulan $B$ & 903 & - & $\begin{array}{l}\text { Desa Kembang Arum, Kec Klegung, } \\
\text { Sleman, DIY }\end{array}$ \\
\hline 11. & Têlang 1 (Wanagiri l) & 903 & $\mathrm{~V}$ & Wonogiri, Jawa Tengah \\
\hline 12. & Têlang II (Wana-giri II) & 903 & $\mathrm{~V}$ & Wonogiri, Jawa Tengah \\
\hline 13. & Kêtanen & 904 & - & \\
\hline 14. & Poh & 905 & V & $\begin{array}{l}\text { Desa Randusari, Kec. Prambanan. Klaten, } \\
\text { Jawa Tengah }\end{array}$ \\
\hline 15. & Kubu-Kubu & 905 & V & $\begin{array}{l}\text { Tidak jelas, dulu koleksi pribadi seseorang } \\
\text { di Malang }\end{array}$ \\
\hline 16. & Kikil Batu I & 905 & - & Tidak jelas (Jawa Tengah) \\
\hline 17. & Kikil Batu II & 905 & $\cdot$ & Tidak jelas (Jawa Tengah) \\
\hline 18. & Rabwan & 905 & $\cdot$ & Tidak diketahui \\
\hline 19. & Palêpangan & 906 & - & $\begin{array}{l}\text { Dari daerah Borobudur, Magelang. Jawa } \\
\text { Tengah }\end{array}$ \\
\hline 20. & Kandangan & 906 & $\cdot$ & Dari daerah Gunungkidul, DIY \\
\hline 21. & Mantyasih I & 907 & $\mathrm{~V}$ & Kedu, Temanggung Jawa Tengah \\
\hline 22. & Mantyasih II & 907 & $\mathrm{~V}$ & Kedu, Temanggung Jawa Tengah \\
\hline 23. & Mantyasih III & 907 & V & $\begin{array}{l}\text { Tidak jelas, diperoleh dari seseorang di } \\
\text { daerah Ngedirejo, Kedu Jawa Tengah, kini } \\
\text { koleksi Museum Nasional. }\end{array}$ \\
\hline
\end{tabular}




\begin{tabular}{|c|c|c|c|c|}
\hline 24. & Rukam & 907 & V & $\begin{array}{l}\text { Desa Petarongan, Kec. Parakan, Te- } \\
\text { manggung, Jawa Tengah }\end{array}$ \\
\hline 25. & Sangsang & 907 & $\mathrm{~V}$ & Tidak jelas (Jawa Timur) \\
\hline 26. & Guntur & 907 & $\cdot$ & Tidak jelas (Jawa Tengah) \\
\hline 27. & Kasugihan & 907 & $\mathrm{~V}$ & Tidak jelas (Jawa Tengah) \\
\hline 28. & Kinêwu & 907 & + & Blitar Jawa Timur \\
\hline 29. & Barsahan & 908 & . & Tidak diketahui asalnya \\
\hline 30. & Sang Makudur & 908 & - & Tidak diketahui asalnya \\
\hline 31. & Turu Manambil & 908 & $\mathrm{~V}$ & Purworejo Jawa Tengah \\
\hline 32. & Wanua Tengah III & 908 & $\mathrm{~V}$ & $\begin{array}{l}\text { Desa Gandulan, Kec. Kaloran, Te- } \\
\text { manggung, Jawa Tengah }\end{array}$ \\
\hline 33. & Wukajana & 908 & - & Tidak diketahui asalnya \\
\hline 34. & Kaladi & 909 & $\mathrm{~V}$ & $\begin{array}{l}\text { Di daerah Gunung Penanggungan, Jawa } \\
\text { Timur }\end{array}$ \\
\hline 35. & Tulangan & 910 & $\therefore$ & Jedung, Mojokerto, Jawa Timur \\
\hline 36. & Taji Gunung & 910 & . & Tidak diketahui \\
\hline 37. & Prasasti "Ambarawa" & hilang & V & Ambarawa, Jawa Tengah \\
\hline
\end{tabular}

Keterangan : $\quad \mathrm{V}=$ penetapan sima

- = lain-lain

(Sumber : Rita Fitriati 1990; Djoko Dwiyanto 1981, dengan penambahan)

\section{PENETAPAN SUATU DAERAH SEBAGAI SIMA}

Prasasti-prasasti dari masa Kerajaan Mataram Kuna yang telah ditemukan kebanyakan berisi tentang penetapan sima. Demikian pula prasasti-prasasti dari masa pemerintahan Balitung, sedangkan peristiwa-peristiwa lain yang terdapat dalam prasasti Balitung adalah tentang penebusan tanah, perhitungan kembali atas luas tanah, pembuatan bendungan, pajak, dan tentang pelaksanaan hukum (Fitriati, 1990: 103).

Penetapan sima pada suatu wilayah merupakan peristiwa yang penting karena menyangkut perubahan status sebidang tanah, yang di dalam masyarakat Indonesia selalu mempunyai hubungan religiomagis dengan penduduk yang tinggal di atasnya. Penetapan suatu daerah sebagai sima merupakan penghargaan pemerintah atau raja atas jasa-jasa seorang pejabat daerah kepada raja atau sebagai anugerah raja untuk kepentingan pendirian bangunan suci (Boechari, 1977: 5).

Di dalam prasasti dijumpai keterangan tentang hari, bulan, tahun, dan unsur-unsur penanggalan lain, yang berhubungan dengan waktu penetapan suatu daerah sebagai sima. Selain itu juga keterangan tentang orang yang menetapkan daerah menjadi sima, orang-orang yang melaksanakan upacara, tentang bermacam-macam upacara yang dilakukan, sumpah atau kutukan bagi yang melanggar ketentuan sima, dan sering pula dijumpai keterangan tentang batas-batas daerah sima tersebut (Boechari, 1977: 5).

Suatu daerah yang telah ditetapkan sebagai sima ternyata tidak seratus persen bebas dari pajak. Sebidang tanah atau suatu daerah yang ditetapkan menjadi sima tidak boleh "dimasuki" lagi oleh sejumlah pejabat tertentu, terutama pankur, tawan, dan 
tirip. Menurut Boechari harus ditafsirkan bahwa para pejabat tersebut tidak lagi dapat menikmati hasil pajak dari daerah itu. Pankur, tawan, dan tirip adalah pejabat yang bertugas mengurusi perbendaharaan kerajaan. Namun sepertiga dari pajak usaha kerajinan dan pajak perdagangan/ penjualan tetap harus diserahkan ke kas kerajaan. Sedangkan pajak tanah atau hasil bumi dan denda-denda atas segala tindak pidana seluruhnya tidak diserahkan ke kas kerajaan, tetapi diperuntukkan bagi pengelola bangunan suci tertentu, atau dinikmati oleh orang yang mendapat anugerah sima itu. Untuk barang dagangan ada ketentuan tentang batas jumlah dagangan yang tidak dikenai pajak apabila dijual di daerah sima (Boechari, 1981: 71, 81). Prasasti Poh menyebutkan bahwa pajak dan suhkaduhkhanya dikhususkan untuk biaya perbaikan

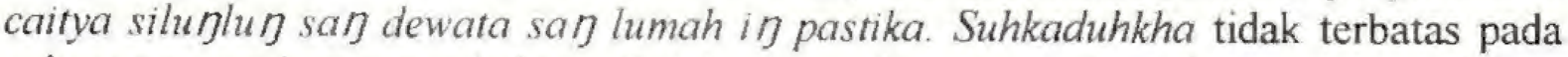
pelanggaran-pelanggaran hukum tindak pidana berupa pembunuhan saja, tetapi juga pencurian, perusakan kebun milik orang lain/ desa tetangga (Kartakusuma, 19941995: 84). Menurut Stutterheim (1940:3-28), saク dewata saク lumah in pastika adalah gelar anumerta Rakai Pikatan, penguasa Kerajaan Mataram Kuna yang beragama

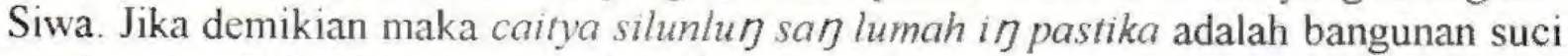
pendarmaan Rakai Pikatan yang bersifat agama Siwa, kemungkinan adalah salah satu di antara candi-candi di kompleks Candi Prambanan (Kartakusuma, 1994-1995:82-83).

Suatu desa yang akan dirubah statusnya menjadi daerah sima - khususnya yang ditugaskan untuk memelihara suatu bangunan suci - haruslah desa yang mempunyai potensi sumberdaya alam yang memadai. Karena tugas yang dibebankan bagi desa tersebut tidak sekedar menyiapkan sajian untuk upacara keagamaan tetapi juga memelihara atau memperbaiki bangunan suci tersebut. Sebagai contoh adalah Desa Poh yang kemungkinan terletak di sebelah utara Candi Prambanan - berdasarkan lokasi temuan Prasasti Poh - mempunyai lahan pertanian yang subur dan dapat menghasilkan biaya-biaya bagi pemeliharaan bangunan suci pendarmaan saク dewata saク lumah in pastika (Kartakusuma, 1994-1995: 84-86)

\section{PERLUASAN WILAYAH MATARAM KUNA PADA MASA BALITUNG}

Wilayah kekuasaan Mataram Kuna pada masa Balitung terletak di daerah-daerah subur bagi lahan pertanian. Bentang lahan wilayah tersebut meliputi lembah-lembah sungai yang kecil di eelah-celah gunung berapi yang terdapat di bagian tengah dan timur Pulau Jawa. Menurut Geertz (1976) di Jawa Tengah daerah pertanian sawah pada masa Mataram Kuna mula-mula terdapat di dataran segi empat yang dibentuk oleh gunung-gunung berapi Sumbing, Sindoro, Merbabu dan Merapi: yaitu di sepanjang Sungai Progo yang mengalir ke selatan di daerah Magelang, di hulu Sungai Solo (Dengkeng) di sebelah barat daya Surakarta, di lembang Sungai Serayu di hulu Banyumas, dan dataran Sungai Lukolo dan Bogowonto di sekitar Kebumen dan Purworejo atau Kedu. 
Berdasarkan distribusi prasasti Balitung yang berkaitan dengan penetapan sima dan distribusi candi baik sebelum maupun semasa pemerintahan Balitung serta tinggalan arkeologis lainnya (lihat tabel 2) terdapat kecenderungan adanya pemusatan tinggalan arkeologis di wilayah lembah-lembah antara Merapi Merbabu dan Sumbing Sindoro. Banyaknya candi maupun prasasti yang terkonsentrasi di kawasan ini menunjukkan bahwa kawasan itu merupakan kawasan penting dan sudah mantap. Sehingga kawasan yang berporos pada wilayah Kedu-Prambanan itu diperkirakan merupakan daerah inti (core). Di luar lingkaran inti tersebut terdapat lingkaran pinggiran (periphery). Kawasan itu antara lain, yang masih agak dekat dengan daerah inti adalah kawasan dengan bentanglahan dataran tinggi dan lembah sekitar Gunung Ungaran, Dieng, dan perbukitan Pembarisan. Di kawasan ini -- yang meliputi wilayah Kabupaten Wonosobo, Semarang, Batang, Kendal, Pekalongan, dan Pemalang - masih terdapat gugusan percandian yang termasuk tua, yaitu percandian Dieng dan Gedongsongo. Namun semakin ke utara dan baratlaut tidak banyak dijumpai lagi bangunanbangunan yang masih utuh, bahkan yang banyak berupa temuan lepas. Tinggalantinggalan arkeologis itu antara lain sisa-sisa bangunan candi di Desa Gonoharjo, Kecamatan Limbangan, Kendal, sisa-sisa bangunan petirtaan di Desa Brokoh, Kecamatan Gringsing, Batang, serta temuan-temuan lain seperti yoni, arca Ganesya, Agastya, Siwa, Durga, dan Nandi (Tjahjono, 1997/1998: 9-15). Di kawasan ini tidak ditemukan prasasti sima masa Balitung.

Ke arah selatan dari kawasan di atas adalah kawasan dengan bentanglahan pegunungan dan lembah Serayu yang meliputi wilayah-wilayah Kabupaten Banjarnegara, Purbalingga, Cilacap, dan Kebumen. Di kawasan ini terdapat sebuah prasasti sima masa Balitung yaitu prasasti Ayamteas II. Di Banjarnegara bagian utara masih terdapat gugusan percandian Dieng. Semakin ke selatan, tinggalan arkeologis berupa bangunan candi semakin berkurang. Lingga dan yoni mendominasi temuan di daerah ini disusul temuan lain berupa arca Ganesya, Nandi, dan komponen-komponen bangunan berupa batu-batu candi, ambang pintu, dan umpak (Tjahjono, 1996/1997:43)

Ke arah barat dan baratlaut dari kawasan di atas adalah bentanglahan lereng dan lembah Gunung Slamet yang meliputi wilayah-wilayah Kabupaten Banyumas, Tegal, dan Brebes. Di kawasan ini tidak ditemukan prasasti sima masa Balitung. Tinggalan arkeologis di kawasan ini antara lain berupa batu-batu candi bersama umpak-umpak batu, lingga, yoni, arca Ganesya, dan nandi (Tjahjono, 1996/1997: 43). Sisa bangunan candi di Desa Bandarsari, Kecamatan Bumijawa, Tegal berupa jaladwara, batu-batu candi, fragmen kemuncak dan pelipit (Abbas, 1995: 5).

Selanjutnya dari sini ke arah tenggara adalah bentanglahan lereng dan lembah pegunungan Menoreh yang meliputi wilayah-wilayah Kabupaten Purworeja dan Kulonprogo. Di kawasan ini cukup banyak terdapat prasasti sima masa Balitung, yaitu 
prasasti Ayamtêas I, Kayu Ara Hiwang, Turu Mangambil, dan mungkin Watukura. Di kawasan ini walaupun tidak ditemukan bangunan suci yang masih utuh, tetapi frekuensi temuan lepasnya cukup banyak, terutama didominasi oleh lingga-yoni, selain itu juga ditemukan struktur bangunan dari bata, antefiks, kemuncak, arca Agastya,Ganesya, Mahakala, dan Nandi (Tjahjono, 1996/1997: 42).

Ke arah timur terdapat bentang lahan dataran tinggi dan lembah di sekitar Pegunungan Selatan yang meliputi wilayah-wilayah Kabupaten Gunungkidul, Sleman bagian selatan, Wonogiri, dan Ponorogo. Di kawasan ini terdapat tiga buah prasasti yaitu Taji, Têlang I dan II. Di wilayah Sleman bagian selatan yang merupakan kawasan pegunungan selatan paling utara terdapat candi-candi Ratu Boko, Banyunibo, dan Ijo. Di Desa Bulurejo, Kecamatan Nguntoronadi, Wonogiri ditemukan sisa-sisa bangunan candi.

Selanjutnya ke arah timur terdapat bentanglahan di lereng dan lembah di antara Gunung-gunung Penanggungan, Welirang, Arjuna, dan Kelud. Kawasan ini meliputi wilayah Kabupaten Mojokerto dan Blitar. Di kawasan ini terdapat prasasti sima masa Balitung yaitu prasasti Kaladi. Sedangkan tinggalan-tinggalan arkeologis baik berupa bangunan suci maupun temuan lepas lain dari masa pra Balitung sampai masa Balitung tampaknya belum ada penelitian secara khusus.

Dari kajian atas distribusi bangunan suci/tinggalan arkeologis dari masa sebelum Balitung sampai masa Balitung dan distribusi prasasti sima masa Balitung pada bentanglahan geografis tampak adanya pemusatan tinggalan arkeologi dan prasasti, selanjutnya semakin keluar dari pusat konsentrasi itu berangsur-angsur intensitasnya semakin berkurang.

Intensitas pengembangan wilayah yang tinggi terdapat di kawasan inti yaitu di daerah Kedu utara dan daerah Prambanan, yang ditunjukkan oleh banyaknya prasasti sima. Pengembangan wilayah ini bisa berupa pengembangan wilayah permukiman desa atau watak, bisa juga pengembangan wilayah pertanian atau tegalan. Kawasan di pinggiran yang menunjukkan perkembangan yang cukup tinggi adalah di kawasan bentanglahan pegunungan Menoreh, yang ditunjukkan oleh prasasti-prasasti Ayamtêas I, Kayu Ara Hiwang, Turu Mangambil, dan Watukura. Hal ini kemungkinan disebabkan karena Raja Balitung berasal dari daerah ini, sehingga setelah menjadi raja daerah kelahirannya juga ikut berkembang. Sedangkan pengembangan ke arah timur (Jawa Timur) dapat ditunjukkan oleh prasasti-prasasti Taji, Têlang, Kubu-kubu, dan Kaladi. Prasasti Têlang menunjukkan adanya jalur transportasi ke timur melalui tempat penyeberangan ferry di Bengawan Solo, sedangkan prasasti Kubu-kubu menunjukkan adanya penverangan ke bantan (Bali/Jawa Timur?). 
Tabel 2. Wilayah distribusi prasasti Balitung dan tinggalan arkeologis masa Mataram Kuno

\begin{tabular}{|c|c|c|c|}
\hline Bentanglahan & $\begin{array}{c}\text { Lokasi } \\
\text { (Kabupaten) }\end{array}$ & $\begin{array}{l}\text { Distribusi prasasti } \\
\text { Balitung tentang } \\
\text { penetapan sima }\end{array}$ & $\begin{array}{c}\text { Distribusi Bangunan } \\
\text { suci /tinggalan } \\
\text { arkeologis lainnya } \\
\end{array}$ \\
\hline $\begin{array}{l}\text { 1) Dataran dan lembah- } \\
\text { lembah di antara Gunung } \\
\text { Merapi - Merbabu } \\
\text { Sumbing } \quad \text { Sindoro. } \\
\text { Dialiri sungai-sungai } \\
\text { Progo, Elo, Opak, Bogo- } \\
\text { wonto }\end{array}$ & 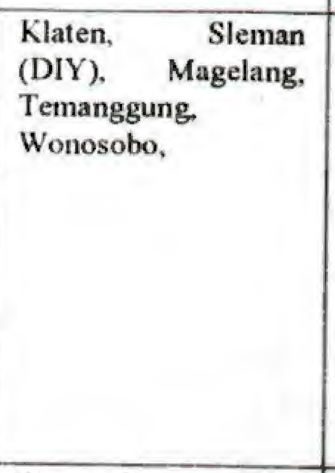 & $\begin{array}{l}\text { Pangumulan A (902), Poh } \\
\text { (905), Rukam (907), } \\
\text { Mantyasih I, II, III (907), } \\
\text { Wanua Tengah III (908). }\end{array}$ & $\begin{array}{l}\text { Padat dengan sebaran } \\
\text { bangunan candi-candi yang } \\
\text { telah ada sebelum masa } \\
\text { Balitung sampai masa } \\
\text { Balitung, Situs-situs itu } \\
\text { antara lain C.Prambanan, } \\
\text { C.Sewu, C.Plaosan, C. } \\
\text { Kalasan, C. Lumbung. C. C. } \\
\text { Borobudur, Mendut, Pawon, } \\
\text { Ngawen, C. Gandosuli, C. } \\
\text { Gunungwukir, C. Perot, C. } \\
\text { Asu, C. Ngawen }\end{array}$ \\
\hline 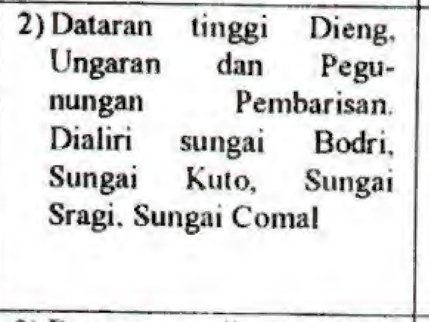 & $\begin{array}{l}\text { Wonosobo, } \\
\text { Kab.Semarang } \\
\text { Batang, Kendal } \\
\text { Pekalongan. } \\
\text { Pemalang. }\end{array}$ & & $\begin{array}{l}\text { Distribusi bangunan suci pra } \\
\text { Balitung, yaitu gugusan } \\
\text { percandian di Dieng dan } \\
\text { Gedongsongo. Temuan lain } \\
\text { berupa sisa-sisa candi, } \\
\text { petirtaan, yoni, lingga, dan } \\
\text { arca-arca Ganesya, Agastya, } \\
\text { Siwa, Durga, Nandi. }\end{array}$ \\
\hline $\begin{array}{l}\text { 3) Dataran di sekitar } \\
\text { Pegunungan Menoreh. } \\
\text { Dialiri sungai Progo, } \\
\text { Bogowonto. Serang }\end{array}$ & $\begin{array}{ll}\text { Purworejo, } & \text { Kulon } \\
\text { Progo (DIY) } & \end{array}$ & $\begin{array}{l}\text { Ayam Teas I }(900 \mathrm{M}) \\
\text { Kayu Ara Hiwang (901). } \\
\text { Turu Manam-bil }(908)\end{array}$ & $\begin{array}{l}\text { Tidak ditemukan bangunan } \\
\text { suci yang masih utuh, hanya } \\
\text { dite-mukan struktur bata, } \\
\text { antefiks, dan fragmen } \\
\text { kemuncak, serta tinggalan } \\
\text { lain berupa temuan lepas } \\
\text { yang didominasi oleh yoni } \\
\text { dan lingga, dan beberapa arca } \\
\text { seperti Ganesya, Agastya, } \\
\text { Nandi, dan Mahakala. }\end{array}$ \\
\hline $\begin{array}{l}\text { 4) Dataran dan lembah di } \\
\text { daerah } \\
\text { Serayu. Degunungan } \\
\text { Serayu }\end{array}$ & $\begin{array}{l}\text { Banjarnegara, Pur } \\
\text { balingga, Cilacap, } \\
\text { Kebumen }\end{array}$ & Ayam Teas II (901) & $\begin{array}{l}\text { Lingga dan yoni masih men } \\
\text { dominasi temuan di daerah } \\
\text { ini-- kecuali di Banjarnegara } \\
\text { utara yang terdapat gugusan } \\
\text { per-candian Dieng--disusul } \\
\text { temuan lain berupa arca } \\
\text { Ganesya, Nandi, dan } \\
\text { komponen-kom-ponen } \\
\text { bangunan berupa batu-batu } \\
\text { candi, ambang pintu, dan } \\
\text { umpak }\end{array}$ \\
\hline $\begin{array}{l}\text { 5) Dataran dan lembah di } \\
\text { sekitar G. Slamet. Dialiri } \\
\text { S. Serayu. S. Rambut, S. } \\
\text { Penali }\end{array}$ & $\begin{array}{l}\text { Tegal, } \\
\text { Banyumas. }\end{array}$ & & $\begin{array}{l}\text { Sisa bangunan candi, struktur } \\
\text { bata, unsur bangunan, yoni. } \\
\text { lingga, arca Ganesya, Nandi, } \\
\text { Siwa Mahaguru }\end{array}$ \\
\hline $\begin{array}{l}\text { 6) Dataran di sekitar } \\
\text { Pegunungan } \\
\text { Dialiri Sungai Oyo, S. } \\
\text { Opak, S. Kedawung }\end{array}$ & $\begin{array}{l}\text { Gunung Kidul dan } \\
\text { Sleman (DIY), } \\
\text { Wonogiri, Ponorogo }\end{array}$ & Taji (901) & $\begin{array}{l}\text { Candi-candi pra Balitung } \\
\text { antara lain Ratu Boko, } \\
\text { Banyunibo, ljo, selain itu juga } \\
\text { ditemukan sisa-sisa bangunan } \\
\text { candi berupa fondasi dan } \\
\text { tubuh di Wonogiri }\end{array}$ \\
\hline
\end{tabular}




\begin{tabular}{|c|c|c|c|}
\hline $\begin{array}{l}\text { 7) Dataran dan lembah di } \\
\text { antara Gunung Penang- } \\
\text { gungan. Welirang. Arjuno } \\
\text { dan Gunung Kelud. Di- } \\
\text { aliri S. Lesti. S. Brantas }\end{array}$ & Mojokerto. Blitar & Kaladi (909) & $\begin{array}{l}\text { Belum ada data bangunan } \\
\text { suci/ tinggalan arkeologis pra } \\
\text { Balitung }\end{array}$ \\
\hline
\end{tabular}

\section{PENUTUP}

Berdasarkan distribusi prasasti dan tinggalan arkeologis lainnya diketahui bahwa wilayah Mataram Kuno terdiri atas wilayah inti (core) dan wilayah pinggiran (periphery). Wilayah dengan padatnya distribusi prasasti dan bangunan-bangunan suci yang memiliki kualitas yang lebih baik dan lebih kompleks, dapat ditafsirkan sebagai wilayah inti (core), sedangkan wilayah yang kurang padat serta berkurang kualitas serta kompleksitas tinggalan arkeologisnya merupakan wilayah pinggiran. Poros Kedu-Prambanan merupakan wilayah inti, sedangkan wilayah pinggiran berada di luar poros Kedu-Prambanan.

Wilayah inti terdiri atas pusat kerajaan (rajya), watak, dan desa (wanua). Wilayah pinggiran meliputi watak dan desa-desa. Pusat kerajaan Mataram Kuno dapat ditelusuri keberadaannya di dacrah Kedu Utara dan di sekitar Prambanan.

Daerah-daerah yang ditetapkan sebagai tanah perdikan (sima) lebih banyak terdapat di wilayah inti, hal ini menunjukkan bahwa wilayah inti mengalami pengembangan wilayah yang lebih intensif daripada wilayah pinggiran. 


\section{KEPUSTAKAAN}

Abbas, Novida dan Lucas Partanda Koestoro. 1995. Survei Arkeologi Islam di sepanjang Pantai Utara Jawa Tengah. Jurnal Penelitian Arkeologi No. 0I, Balai Arkeologi Yogyakarta.

Boechari, 1977. Epigrafi dan Sejarah Indonesia. Majalah Arkeologi, tahun I No 2. Jakarta: Lembaga Arkeologi Fakultas Sastra Universitas Indonesia, hlm. 1-40.

Boechari, 1981. Ulah Para Pemungut Pajak di dalam Masyarakat Jawa Kuna. Majalah Arkeologi, tahun IV, no. 1-2. Fakultas Sastra Universitas Indonesia, him. 67-87.

Casparis. J.G de. 1956. Selected Inscriptions From 7th to The 9th Century AD. Prasasti Indonesia II. Bandung: Masa Baru.

Christie, Jan Wisseman. 1989. Raja dan Rama Negara Klasik Awai di Jawa dalam Pusat, Simbol, dan Hirarki Kekuasaan. Jakarta: Yayasan Obor Indonesia.

Dwiyanto, Djoko. 1981. Beberapa Masalah Transportasi Di Jawa Tengah Pada Masa Pemerintahan Balitung (tahun 899-910), skripsi pada Fakultas Sastra dan Kebudayaan Universitas Gadjah Mada.

Fitriati, Rita. 1990. Pasak-pasak Dari Masa Balitung dan Sindok, Monumen, Lembaran Sastra seri penerbitan Ilmiah No. 11 edisi khusus Fakultas Sastra Universitas Indonesia.

Kartakusuma. Richadiana, 1994-1995. Tinjauan Kembali Isi Prasasti Poh (827S/907M): Sedikit Catatan Tentang Alasan Pemilihan Suatu Daerah Perdikan. Analisis Sumber Tertulis Masa Klasik. Jakarta: Proyek Penelitian Purbakala Jakarta.

Kusen, nfn. (1994). Raja-raja Mataram Kuna dari Sanjaya Sampai Balitung Sebuah Rekonstruksi Berdasarkan Prasasti Wanua Tengah III. Berkala Arkeologi, 14(2), 82-94. https:// doi.org/10.30883/jba.v14i2.721

Nastiti, dkk., 1982. Tiga Prasasti Dari Masa Balitung. Jakarta: Pusat Penelitian Arkeologi Nasional. 
Poerbatjaraka. 1930. De Naam Dharmawangca. TBG LXX: 171-183.

Rangkuti, N. (1994). Emas dan Tanah: Kasus Penguasaan Sumber-sumber Ekonomi di Sumatera dan Jawa Pada Abad VII-X Masehi (Kajian Prasasti-prasasti Masa Sriwijaya dan Mataram Kuna). Berkala Arkeologi, 14(2), 163-169. https://doi.org/10.30883/jba.v14i2.716

Schrieke. B.J.O., 1975. Ruler and Realm in Early Java, Indonesian Sociological Studies, part two. Bandung: The Hague.

Stutterheim. W .F.. 1940. Oorkonde Van Balitung Uit 905 AD (Randusari I), INI. Afls Gravenhage: Martinus Nijhoff.

Tjahjono. Baskoro Daru. 1996/ 1997. Budaya Marginal Masa Klasik di Jawa Tengah Bagian Baratdaya, Jurnal Penelitian Arkeologi No. 04, Balai Arkeologi Yogyakarta, him. 41-46.

Tjahjono. Baskoro Daru. 1997/1998. Penelitian Budaya Marginal pada Masa Klasik di Jawa Tengah bagian Baratlaut Tahap I, Laporan Hasil Penelitian Arkeologi, Balai Arkeologi Yogyakarta.

Wibowo, A.S., 1964. Sedikit Tentang Tahun Permulaan Pemerintahan Balitung, M.I.S.1., jilid II, no.2, him. 147-154.

Wibowo, A.S., 1976. Balitung Pernah Menyerang Bali Tahun 827 C. Bulletin Yaperna, no.I I, Th.III, him. 64-76. 


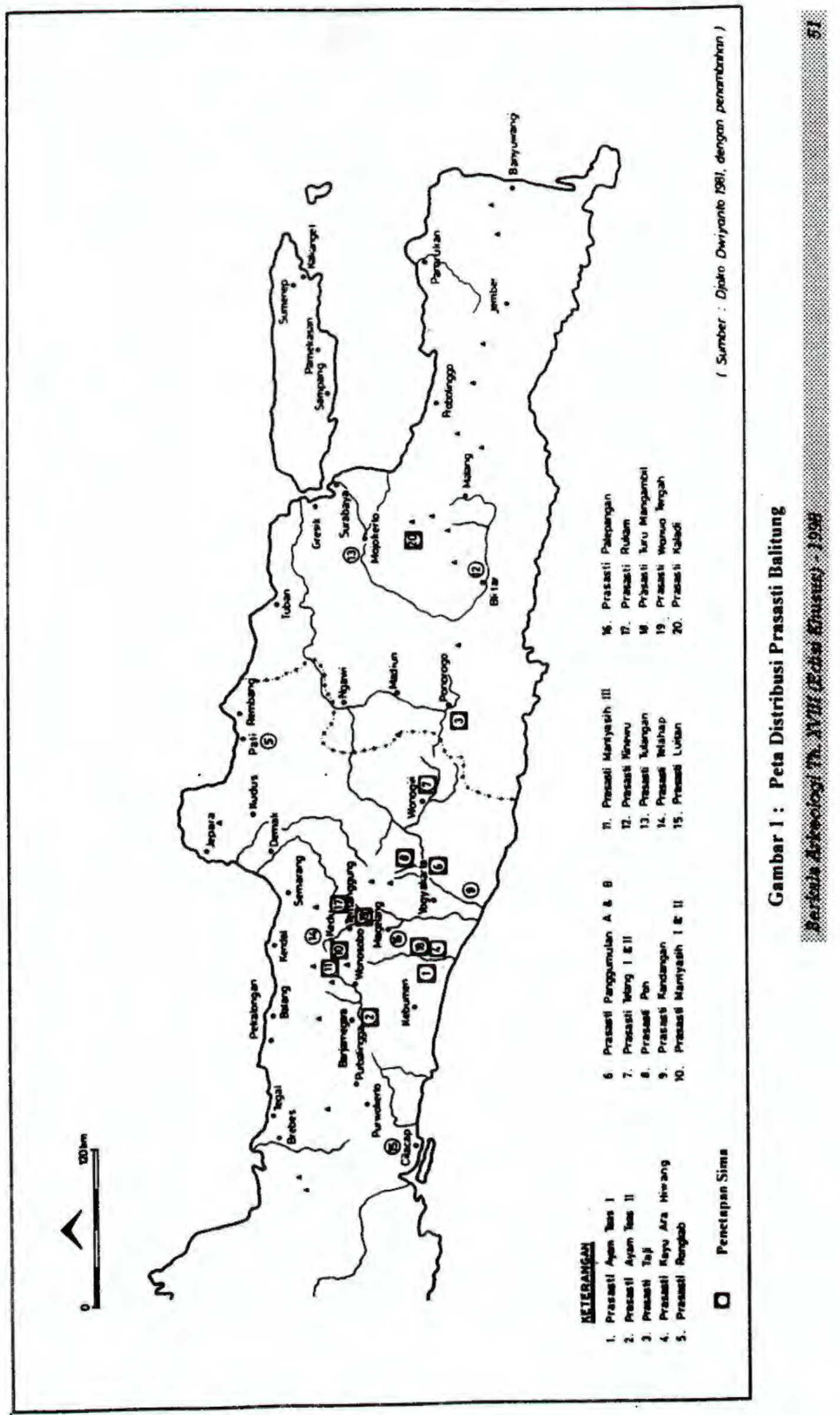




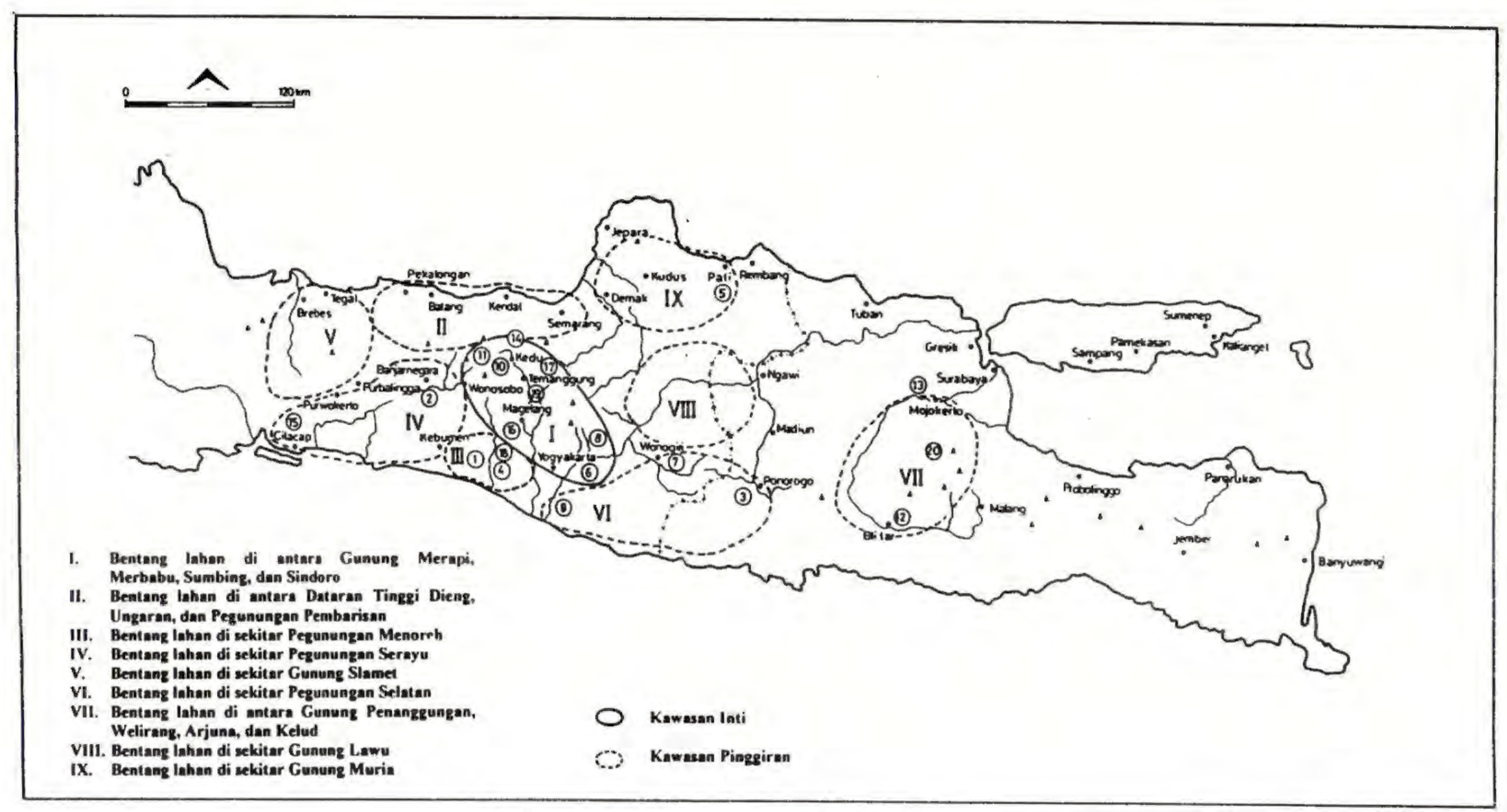

Gambar 2 : Peta Kawasan Inti dan Pinggiran

Pada Masa Mataram Kuna 